\title{
Surgical site infections post cesarean section
}

\author{
Sundari Lakshmi Devi, D. V. K. Durga* \\ Department of Obstetrics and Gynecology, Gandhi Medical College, Secunderabad, Telengana, India
}

Received: 15 April 2018

Accepted: 08 May 2018

\section{*Correspondence:}

Dr. D. V. K. Durga,

E-mail: dadedurga@gmail.com

Copyright: $\odot$ the author(s), publisher and licensee Medip Academy. This is an open-access article distributed under the terms of the Creative Commons Attribution Non-Commercial License, which permits unrestricted non-commercial use, distribution, and reproduction in any medium, provided the original work is properly cited.

\section{ABSTRACT}

Background: Surgical site infections are among the most common hospital acquired infections. They make upto 14$16 \%$ of inpatient infections. Objective of present study was to evaluate the risk factors associated with surgical site infections and the bacteria causing wound infections in obstetric operations and the antibiotic sensitivity and resistance pattern of the pathogens isolated.

Methods: 100 women with wound infection during hospital stay or within 30 days following surgery. Pus samples were collected from the wound site with help of sterile swabs under aseptic precautions and immediately transported to microbiology laboratory for culture and sensitivity.

Results: Most of the patients belonged to the age group of 21-25 years, contributing to 55\% of the cases. Majority of the women are from rural areas (71\%). 57\% of the cases were unbooked. $90 \%$ of the SSI were seen in emergency surgeries. Anaemia (48\%) was the most common medical risk factor followed by hypertensive disorders $25 \%$. The risk of post operative infection has been shown to be proportional to volume of blood loss during cesarean section and duration of surgery. Staphylococcus aureus to be predominant organism of wound infection of which $21 \%$ were MRSA followed by Klebsiella and E.coli. The gram negative isolates were $100 \%$ resistant to ampicillin followed by $22.5 \%$ to third generation cephalosporins and aminoglycosides.

Conclusions: Proper assessment of risk factors that predispose to SSI is critical for the development of strategies for reducing the incidence of SSI and for identifying high risk patients requiring intensive postoperative surveillance.

Keywords: Antibiotics, Cesarean, Infection, Surgical site infections

\section{INTRODUCTION}

Surgical site infections are among the most common hospital acquired infections. They make upto $14-16 \%$ of inpatient infections. ${ }^{1}$

The increasing incidence of cesarean deliveries worldwide has contributed to greater wound morbidity. ${ }^{2}$

The incidence of cesarean section in india was $7.1 \%$ in 1998 and there is $16.7 \%$ rise in the rates annually in India. $^{3}$ The rates of SSI are considered as an indicator of the quality of surgical and postoperative care provided by the hospitals. ${ }^{4}$
Knowledge of the organisms causing SSI and their antibiotic sensitivity and resistance patterns provide an insight into the current antibiotic prescription practices and the factors affecting these practices. The present study helps to know the risk factors and the organisms causing SSI in our hospital and their sensitivity to different antibiotics which help in formulating infection control practices.

\section{METHODS}

This was a cross sectional descriptive study conducted at Niloufer hospital between 2013 to 2015 with a sample size of 100 . 


\section{Inclusion criteria}

- Women with wound infection during hospital stay or within 30 days following surgery, using the criteria for CDC5 (The center for disease control and prevention)

- The operations included are Caesarean section, lapratomy for uterine rupture including rent repair and peripartum hysterectomy.

\section{Exclusion criteria}

- Women with wound infection after 30 days following surgery, Surgeries in $1^{\text {st }}$ trimester i.e lapratomy for ectopic pregnancies and molar pregnancies

- Women who fulfill the inclusion criteria are enrolled in the study. Diagnostic criteria were maternal fevers accompanied by spontaneous parting of wound or purulent discharge from the wound with or without positive bacterial culture/local swelling. ${ }^{6}$

- Demographic information, potential risk factors, operative findings, the amount of blood loss are recorded. Pus sample collected from the wound sent for culture and sensitivity.

\section{RESULTS}

Most of the patients belonged to the age group of 21-25 years, contributing to $55 \%$ of the cases.

Majority of the women are from rural areas (71\%). 57\% of the cases were unbooked.

Most of them belong to primi gravida (59\%).

Table 1: Demographic distribution in study.

\begin{tabular}{|lll|}
\hline Parameters & Number of cases & Percentage \\
\hline Maternal age & & \\
\hline$<20$ & 5 & 5 \\
\hline $21-25$ & 55 & 55 \\
\hline $26-30$ & 33 & 33 \\
\hline$>30$ & 7 & 7 \\
\hline Nativity & & \\
\hline Rural & 71 & 71 \\
\hline Urban & 29 & 29 \\
\hline Antenatal visits & & \\
\hline Booked & 43 & 43 \\
\hline Unbooked & 57 & 57 \\
\hline Gravidity & & \\
\hline Primi & 59 & 59 \\
\hline Gravida 2 & 29 & 29 \\
\hline Gravida 3 & 10 & 10 \\
\hline Gravida 4 & 2 & 2 \\
\hline
\end{tabular}

$90 \%$ of the SSI were seen in emergency surgeries (Figure $1)$.

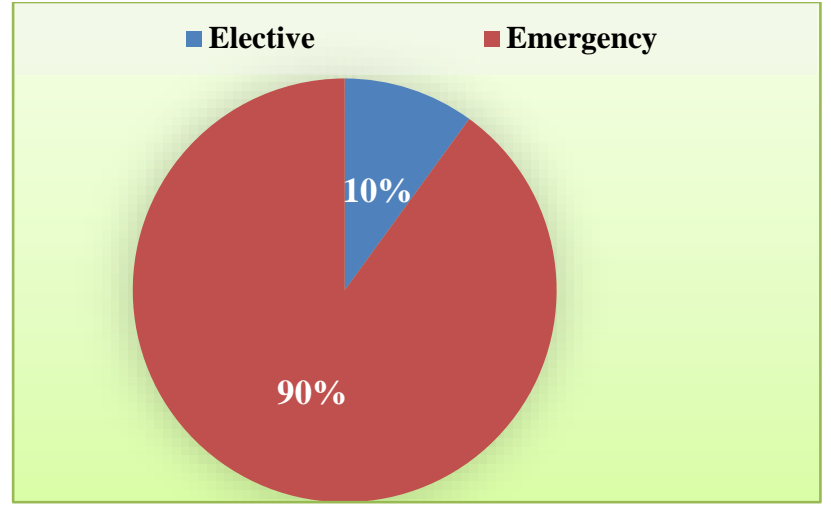

Figure 1: Circumstances of surgery.

Almost all cases are of cesarean section (Table 2).

Table 2: Types of surgery.

\begin{tabular}{|lll|}
\hline Type of surgery & No. of cases & Percentage \\
\hline Cesarean section & 90 & 90 \\
\hline Uterine repair & 5 & 5 \\
\hline Peripartum hysterectomy & 5 & 5 \\
\hline
\end{tabular}

Table 3: Risk Factors.

\begin{tabular}{|l|l|}
\hline Medical risk factor & No. of cases \\
\hline Anemia & 51 \\
\hline Hypertensive disorders & 25 \\
\hline Diabetes & 09 \\
\hline Jaundice & 03 \\
\hline Hypothyroidism & 02 \\
\hline HIV+ve & 04 \\
\hline Ascitis & 05 \\
\hline Obstetric risk factors & \\
\hline Prev. LSCS & 30 \\
\hline Rupture Uterus & 05 \\
\hline Failed Induction & 15 \\
\hline Placenta Previa & 05 \\
\hline Placenta Acreta & 02 \\
\hline Abrution & 04 \\
\hline DIC & 04 \\
\hline PROM & 27 \\
\hline Chorioamnitis & 08 \\
\hline
\end{tabular}

Table 4: Duration of surgery, ruptured membranes and Intra operative blood loss.

\begin{tabular}{|lcc|}
\hline \multicolumn{2}{|c|}{ No. of cases } & Percentage \\
\hline Duration of surgery & \multicolumn{2}{|c|}{} \\
\hline$<1$ hour & 82 & 82 \\
\hline$>1$ hour & 18 & 18 \\
\hline Duration of ruptured membranes & \\
\hline$<8$ hrs & 10 & 10 \\
\hline$>8$ hrs & 17 & 17 \\
\hline Intra operative blood loss & \\
\hline$<1000 \mathrm{ml}$ & 78 & 78 \\
\hline$>1000 \mathrm{ml}$ & 22 & 22 \\
\hline
\end{tabular}


Anemia is most common medical risk factor in the patients. Previous LSCS is most effected patients with obstetric risk factor (Table 3).

In $82 \%$ cases duration of surgery is more than 1 hour and duration of ruptured membrane is $>8 \mathrm{hrs}$. Blood loss during surgery is less than $1000 \mathrm{ml}$ in $78 \%$ of patients (Table 4).

Table 5: Organisms isolated from the pus.

\begin{tabular}{|ll|}
\hline Organisms isolated & No. of cases \\
\hline Staphylococcus aureus & 36 \\
\hline Klebsiella & 23 \\
\hline Escherichia coli & 18 \\
\hline Pseudomonas & 6 \\
\hline No growth & 17 \\
\hline
\end{tabular}

Staphylococcus aureus is most common organism isolated in pus after culture (Table 5).

Table 6: Antibiotic sensitivity pattern of the Staphylococcus aureus.

\begin{tabular}{|lll|}
\hline Antibiotic & MRSA & MSSA \\
\hline Penicillin & $0(0 \%)$ & $21(70 \%)$ \\
\hline Oxacillin & $0(0 \%)$ & $30(100 \%)$ \\
\hline Tetracycline & $2(25 \%)$ & $15(50 \%)$ \\
\hline Linezolid & $8(100 \%)$ & $30(100 \%)$ \\
\hline Levofloxacin & $8(100 \%)$ & $30(100 \%)$ \\
\hline Clindamycin & $4(50 \%)$ & $23(76 \%)$ \\
\hline Ciprofloxacin & $2(25 \%)$ & $15(30 \%)$ \\
\hline Vancomycin & $8(100 \%)$ & $30(100 \%)$ \\
\hline Erythromycin & $2(25 \%)$ & $23(76 \%)$ \\
\hline Gentamycin & $4(50 \%)$ & $24(80 \%)$ \\
\hline
\end{tabular}

Staphylococcus aureus to be predominant organism of wound infection of which $21 \%$ were MRSA. The gram negative isolates were $100 \%$ resistant to ampicillin followed by $22.5 \%$ to third generation cephalosporins and aminoglycosides (Table 6).

\section{DISCUSSION}

SSI is the second most common infectious complication after urinary tract infection following cesarean delivery7. It is a surgical complication with a high morbidity rate, but it is associated with predictable and preventable risk factors. The majority of patients in our study group belong to the age group of 21 to 25 years could be because most pregnant women fall within this age distribution and $71 \%$ from rural areas and $29 \%$ from urban areas (Table 1).

This is consistent with the Amenu D et al study. ${ }^{8}$ Obstetric care services should be strengthened in rural areas. $59 \%$ of the patients were nulliparous which is similar to that of study in Mitt et al. ${ }^{9}$ Tran et al reported that the risk factor of surgical site infection was shown to be reduced by $39 \%$ and $60 \%$ when women had one or more children respectively. ${ }^{10}$ Majority of the cases were unbooked which correlates with Amenu D et al study. ${ }^{8}$ Antenatal care provides opportunities for health education, prior detection and correction of maternal problems.

Patients with anemia were seen to be more prone to SSI. Anemia diminishes resistance to infection and is frequently associated with puerperal sepsis. In present study $48 \%$ of the patients had anemia which is consistent with Devjani et al study. ${ }^{11}$ Poor control of glucose during surgery and in the perioperative period increases the risk of infection and worsens outcome of sepsis. The results of present study are consistent with Olsen MA et al study. ${ }^{12}$ Hypertensive disorders were seen in $25 \%$ of the women in our study which correlates with incidence seen in Schneid - Kofman et al study. ${ }^{6}$

$30 \%$ of the cases in our study had a repeat CS which correlates with Olsen MA et al study. ${ }^{12}$ PROM is seen in $27 \%$ of cases. PROM associated with the largest bacterial inoculum and liquor gets infected and infection supervenes. ${ }^{13}$ The incidence of chorioamnionitis was $8 \%$ consistent with Al Jama FE study of Qatar.

An obstetric related risk factor of both intrinsic and extrinsic origin is length of time that the membranes are ruptured prior to cesarean section (Figure 1 and Table 2). Following membrane rupture, the amniotic fluid is no longer sterile and may act as a transport medium by which bacteria come into contact with the uterine and skin incisions. ${ }^{14}$ The increased incidence of SSI in cases with intact membranes may be due to multiple vaginal examinations in cases with failed induction and other coexisting risk factors. The duration of surgery is more than one hour in 18 cases, (Table 3) Shapiro et al reported that with each hour of surgery the infection rate almost doubles. ${ }^{15}$ The risk of postoperative infection has been shown to be proportional to volume of blood loss during cesarean section (Table 4). ${ }^{16,17}$ Risk of surgical site infection increased by $30 \%$ for every $100 \mathrm{ml}$ blood loss. A high volume of blood loss is usually associated with poor control of bleeding increased tissue damage from prolonged retraction and manipulation and more sutures 18 . Blood loss of more than $1000 \mathrm{ml}$ was in 22 cases similar to that in the Amenu D et al study. ${ }^{8}$

Majority of the SSI, $63 \%$ required secondary suturing while in $37 \%$ of the cases, the wound healed with daily aseptic dressings and secondary intention. The most common pathogenic organisms causing SSI in present study (Table 5 and 6) were found to be S. aureus $35 \%$ followed by gram negative rods of which Klebsiella species $24 \%$, E. coli. $18 \%$. $44 \%$ S. aureus strains were found to be resistant to penicillin. Ineffectiveness of penicillin in $S$. aureus has been also reported in other studies. ${ }^{15,19}$. E. coli, Klebsiella, Pseudomonas were $100 \%$ sensitive to piperacillin and ticarcillin. 


\section{CONCLUSION}

SSI is more prevalent among emergency procedures and women who were unbooked. It is important for antenatal women to have regular antenatal visits so that modifiable risk factors like anaemia are corrected before term. Staphylococcus aureus was predominant organism of wound infection of which $21.05 \%$ were MRSA followed by Klebsiella and E. coli. Antibiotic use should be vigilant as MRSA was $100 \%$ resistant to penicillin, oxacellin and $75 \%$ to erythromycin, ciprofloxacin and tetracyclin. Proper assessment of risk factors that predispose to SSI is critical for the development of strategies for reducing the incidence of SSI and for identifying high risk patients requiring intensive postoperative surveillance.

\section{Funding: No funding sources}

Conflict of interest: None declared

Ethical approval: The study was approved by the Institutional Ethics Committee

\section{REFERENCES}

1. Skarzyńska J, Cienciała A, Madry R, Barucha P, Kwaśniak M, Wojewoda T etal. Hospital infection in general surgery wards. Przegl Epidemiol. 2000;54(34):299-304.

2. Van schalkwyk J, van Eyk N. Society of obstetricians and Gynaecologists of Canada Infectious disease committee. Antbiotic prophylaxis in obstetric procedures. J obstet Gynaecol Can. 2010;32(9):878-92.

3. Stanton CK, Holtz SA. Levels and trends in cesarean birth in the developing world. Stud Fam Plann. 2006;37(1):41-8.

4. Gaynes RP. Surveillance of nosocomial infections: a fundamental ingredient for quality. Infect Control Hosp Epidemiol. 1997;18(7):475-8.

5. Horan TC, Gaynes RP, Martone WJ, Jarvis WR, Emori TG. CDC definitions of nosocomial surgical site infections, 1992: a modification of CDC definitions of surgical wound infections. Infect Control Hosp Epidemiol. 1992;13(10):606-8.

6. Schneid-kofman N, Sheiner E, Levy A, Holcberg G. Risk factors for post caesarean surgical site infection Obstet Gynaecol. 2000;95(3):367-71.

7. Hillan EM. Postoperative morbidity following Cesarean delivery. J Adv Nurs. 1995;22(6):1035-42.

8. Amenu D, Belachew T, Araya F. Surgical site infection rate and risk factors among obstetric cases of Jimma university specialized hospital, southwest Ethiopia. Ethiop J Health Sci. 2011;21:91-100.

9. Mitt P, Lang, K, Peri A, Maimets M. Surgical-site infections following cesarean section in an Estonian university hospital: post discharge surveillance and analysis of risk factors. Infect Control Hosp Epidemiol. 2005; 26(5): 449-54.

10. Claesson BE, Holmlund DE. Predictors of intraoperative bacterial contamination and postoperative infection in elective colorectal surgery. J Hosp Infect. 1988;11(2):127-35.

11. De D, Saxena S, Mehta G, Yadav R, Dutta R. Risk factors analysis and microbial etiology of surgical site infections following lower segment caesarean section. Int J Antibiot. 2013;10:1155-60.

12. Oslen MA, Buttler AM, Willers DM, Devkota P, Gross GA, Fraser VJ. Risk factors for surgical site infections after low transverse caesarean section. Infect Control Hosp Epidemiol. 2008;29(6):477-84.

13. Dr. C. Dutta. "Medical and surgical illness complicating pregnancy". Textbook of obstetrics. H. konar, ed;2004; Central $6^{\text {th }}$ edition, 262-305.

14. Allegranzi B, Nejad SB, Combescure C, Graafmans W, Attar H, Donaldson L, Pittet D. Burden of endemic health-care-associated infection in developing countries: systematic review and metaanalysis. Lancet. 2011;377(9761): 228-41.

15. Shapiro M, Muñoz A, Tager IB, Schoenbaum SC, Polk BF. Risk factors for infection at the operative site after abdominal or vaginal hysterectomy. N Engl J Med. 1982;307(27):1661-6.

16. Hagglund L, Christenson KK, Christenson P, Kammec. Risk factors in caesarean section infection Obstet Gynaecol. 1988;72:559-64.

17. Ott WJ. Primary caesarean section; factors related to postpartum infection. Obstet Gynaecol. 1981;57: 171-6.

18. Trans TS, Jamulitrat $\mathrm{S}$, chongsuvivatwong $\mathrm{V}$, Geater A. Risk factors for post cesarean surgical site infection. Obstet Gynaecol. 2000;95(3):367-71.

19. Lilani SP, Jangale N, Chowdhary A, Daver GB. Surgical site infection in clean and cleancontaminated cases. Indian $\mathbf{J}$ Med Microbiol. 2005;23(4):249.

Cite this article as: Devi SL, Durge DVK. Surgical site infections post cesarean section. Int J Reprod Contracept Obstet Gynecol 2018;7:2486-9. 